\title{
Dietary Shifts by Green Turtles (Chelonia mydas) in the Kāne'ohe Bay Region of the Hawaiian Islands: A 28-Year Study ${ }^{1}$
}

\author{
Dennis 7. Russell ${ }^{2}$ and George H. Balazs ${ }^{3}$
}

\begin{abstract}
The green turtle, Chelonia mydas, has modified its feeding behavior to include the increasing abundance of nonnative algae growing in the greater Kāne'ohe Bay area of O'ahu in the Hawaiian Islands. Changes in diet of the green turtle are correlated with an increase in abundance of seven species of nonnative algae between 1977 and 2005. Turtles were found to be eating 130 species of marine vegetation, and the three most common were the nonnative species Acanthophora spicifera, Hypnea musciformis, and Gracilaria salicornia. These three abundant and nutritious food sources are now an important part of the turtle diet in addition to native species found in and near Kāne'ohe Bay. Chelonia mydas behavior has shifted to include these new seaweeds within 10 years of their introduction to the region. The turtles have also gradually included an additional four less-prolific slow-growing nonnative algal species (Eucheuma denticulatum, Gracilaria tikvabiae, Kappaphycus striatum, and Kappaphycus alvarezii), but the time it has taken turtles to include these species has been longer, 20-30 years, after the seaweeds were introduced. During this same 28-year time period numbers of $C$. mydas have increased throughout the Hawaiian Islands.
\end{abstract}

The feeding Behavior and diet of the herbivorous green turtle, Chelonia mydas (L.), have been the subject of 28 years of research conducted between 1977 and 2005 throughout the Hawaiian Archipelago and especially in the vicinity of Kāne'ohe Bay, Hawai' $i$ (Figure 1). The green turtle has shown a remarkable ability to rebound from decline, largely due to conservation measures, such as protection from harvesting and other forms of take under the U.S. Endangered Species Act, and now the population is recovering (Balazs and Chaloupka 2004a, 2006). However, a decline in the somatic growth rates of the turtles indicates that the population may

\footnotetext{
${ }^{1}$ Manuscript accepted 10 July 2008.

${ }^{2}$ Department of Biology, Chemistry, and Environmental Sciences, American University of Sharjah, P.O. Box 26666, Sharjah, United Arab Emirates (e-mail: drussell@aus.edu).

${ }^{3}$ NOAA, National Marine Fisheries Service, Pacific Islands Fisheries Science Center, 2570 Dole Street, Honolulu, Hawai'i 96822-2396.
}

Pacific Science (2009), vol. 63, no. 2:181-192

(C) 2009 by University of Hawai'i Press

All rights reserved be approaching carrying capacity and now available food may be limiting growth at some locations (Balazs and Chaloupka 2004b). Shifts in the diet of the green turtle in Kāne'ohe Bay may be fortuitous for the turtles and their continuing recovery. This paper focuses on the ability of green turtles to modify their feeding behavior and take advantage of additional algal food sources.

Although understanding all aspects of green turtle biology is critical for the recovery of the species (Hirth 1997), one of the more important conservation topics involves turtle feeding behavior, which includes knowledge of the species of algae, sea grasses, animals, and other items C. mydas is eating, and eventually protecting the most important foraging sites and food species they are utilizing (Balazs 1980, Hirth 1997, Russell et al. 2003). It has been known for many years that $C$. mydas feeds on a wide variety of marine vegetation (Balazs et al. 1987, Russell and Balazs 1994, Arthur and Balazs 2008). Data from the feeding habits of $C$. mydas have also been used to discover changes in the feeding behavior of C. mydas, which include nonnative species in its diet, and to follow the spread of Hypnea musciformis, a nonnative species, from its 


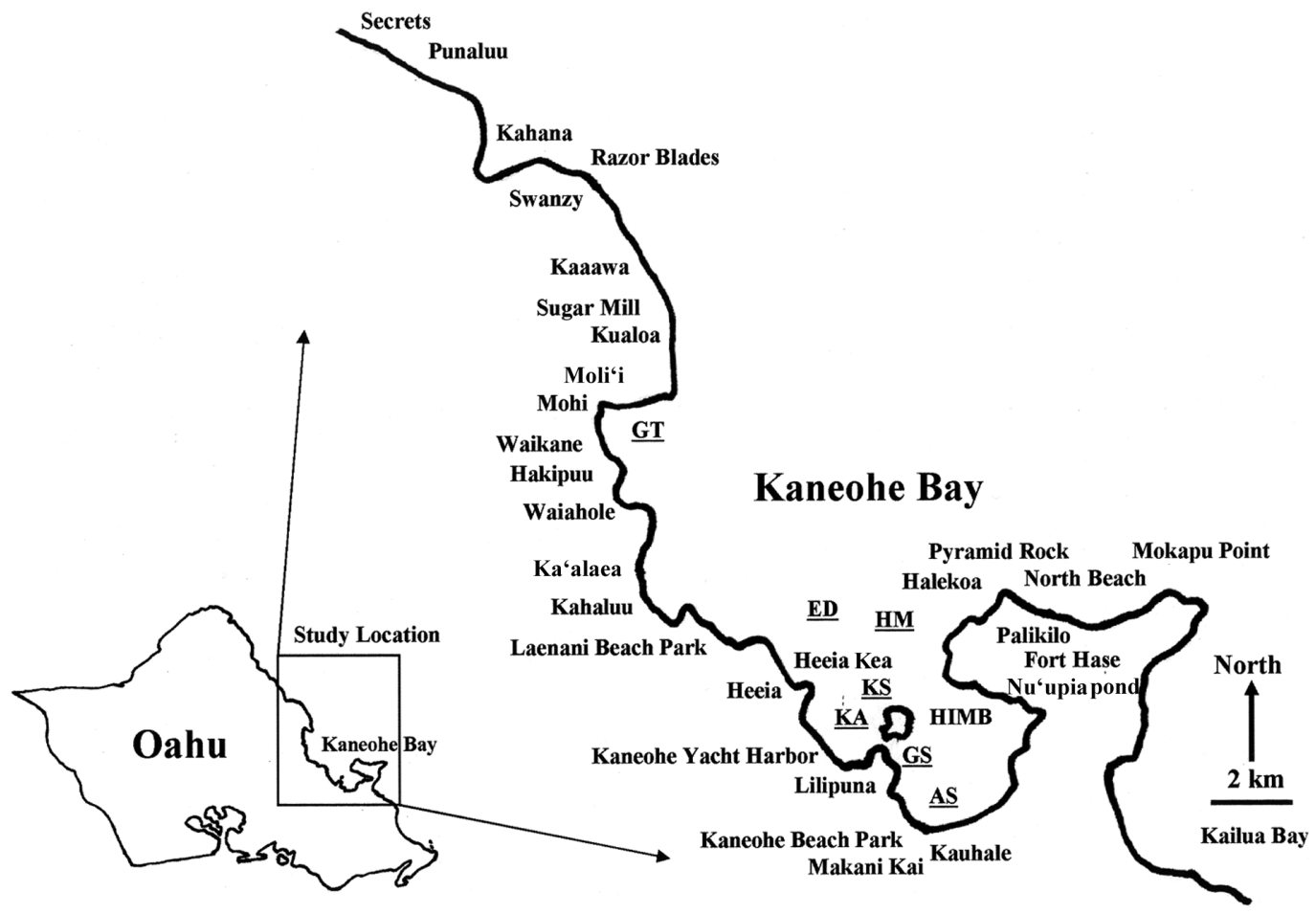

Figure 1. O'ahu, Hawai'i, showing the location of the study: the Kāne'ohe Bay region including adjacent shores, the locations where stranded turtles were found, and the initial locations where nonnative algae were introduced. AS, $A$. spicifera; HM, H. musciformis; GS, G. salicornia; ED, E. denticulatum; GT, G. tikvabiae; KA, K. alvarezii; KS, K. striatum.

place of introduction on $\mathrm{O}^{6} \mathrm{ahu}$ to the other Hawaiian Islands (Russell and Balazs 1994, Smith et al. 2002). Another study relating to the two sea-grass species Halophila hawaiiana and $H$. decipiens revealed that $C$. mydas had adjusted its feeding according to the abundance of these two sea-grass species, and as $\mathrm{H}$. decipiens became more abundant the turtles began feeding on it in addition to $H$. bawaiiana (Russell et al. 2003).

Our turtle diet study was initiated in the same decade when several species of marine algae were introduced to Hawai' $i$ in the 1970s (Russell 1981, 1992, Eldredge and Smith 2001). The greater Kāne'ohe Bay area was a critical location for the study of green turtle feeding behavior because many of the new transplants of nonnative algal species went directly into Kāne'ohe Bay (Russell 1983, 1992), and it was known when and where they were introduced (Figure 1). In this paper we investigate the hypothesis that $C$. mydas has modified its feeding behavior to include nonnative, introduced species of algae into its diet as they became more abundant in this well-known turtle foraging location.

\section{MATERIALS AND METHODS}

Green turtles feed in foraging locations by nipping off small pieces of algae, sea grasses, and other food items with their beaks, pressing the water out on the roof of their mouth and swallowing. This gives a uniform size to the food items, which can be spread uniformly on a petri plate without further manipulation or maceration. The algae, sea grass, and other material become packed into a crop, a pouch located in the posterior region of the esophagus (Balazs et al. 1998, Work 2000). Diet samples for our study were obtained from stranded dead turtles at 
the time of necropsy; each sample represents the necropsy of one turtle. Carcasses were salvaged for necropsy through a widely publicized sea turtle stranding research program (Chaloupka et al. 2008). Analysis was done, using SPSS 15.0 (SPSS Inc., Chicago), on 372 samples from turtles found at 31 locations in the Kāne'ohe Bay area (Figure 1) from 1977 to 2005, from Kahana to Mōkapu Point (Figure 1). Sampling was entirely dependent on the finding and reporting of stranded dead turtles, and this led to receiving up to 38 samples each year. The average number of samples received was 12.3 year; during 1982-1984 there were no samples, therefore interpolated data were used for those 3 years.

One $50 \mathrm{ml}$ sample was taken from the crop of each turtle, preserved in 10\% formalin/ seawater, and analyzed microscopically by D.J.R. (Russell and Balazs 2000). Identification of major algal species and sea grasses was based on the latest knowledge of algae available at the time and later modified to show the most up-to-date taxonomy possible (Phillips and McRoy 1980, Abbott 1999, Abbott and Huisman 2004, Huisman et al. 2007).

The entire $50 \mathrm{ml}$ sample was suspended evenly and poured into a $2 \times 14 \mathrm{~cm}$ petri plate with 32 squares $(2 \times 2 \mathrm{~cm})$ etched into the bottom. The sample was examined under a stereomicroscope and the species fragments sorted onto the squares, which were counted and converted into percentages. The percentages represent both the surface area covered by each species and are also a measure of the volume they represent $(1.6 \mathrm{ml}$ of sample covers each $2 \times 2 \mathrm{~cm}$ square). Examination ended when all the trace species were recorded using a compound microscope. Trace species were those that represented less than $1 \%$ of the sample. Frequency represents the proportion of samples in which the diet items were observed and the average percentage represents the proportion that the diet species contributed to the total samples.

\section{RESULTS AND DISCUSSION}

Green turtles in Kāne'ohe Bay were eating 130 species, mostly marine algae, but also two species of sea grasses (Table 1). Of the 130 species, $81(62.3 \%)$ were found in trace amounts because they either were nearly microscopic or occurred in small amounts and only one to three times out of the total 372 samples (Table 1). Acanthophora spicifera was found in more samples $(64.0 \%)$ than any other species, followed by Hypnea musciformis (41.4\%) and Gracilaria salicornia (37.0\%); each of these is a nonnative alga (Russell 1981, 1992). Four additional nonnative algae species were also present in the samples: Eucheuma denticulatum (2.2\%), Kappapbycus alvarezii (1.3\%), Kappaphycus striatum (1.1\%), and Gracilaria tikvahiae (0.8\%). A few native species were present in nearly all of the samples $(98 \%)$, but only three nonnative species contributed more than $40 \%$ of the amount eaten by the turtles (Figure 2, Table 1). Only 22 species, or $16.9 \%$ of the total number of species, accounted for $>4 \%$ occurrence in the turtles' food items (Table 1). The remaining 108 species were either sparse or microscopic in size and found as trace amounts. The most important native species, in order of their contribution values to the turtle diet, were Pterocladiella capillacea, Codium edule, Amansia glomerata, Codium arabicum, Halophila bawaiiana, Dictyosphaeria cavernosa, and Spyridia filamentosa. This indicates that the three nonnative species were contributing an important proportion of the green turtle diet when compared with native species.

The history of algal introductions into Kāne'ohe Bay has been well documented (Russell 1981). Acanthophora spicifera was the first nonnative seaweed recorded for the Hawaiian Islands. It entered $\mathrm{O}^{\prime}$ ahu on the leeward side, probably as fouling on a barge from Guam, into Pearl Harbor, in 1950 and by 1954 was found growing on reefs in the Kāne'ohe Bay region. By 1956 it had also spread to Kaua'i and other Hawaiian Islands (Doty 1961). Studies between 1978 and 1993 showed that $A$. spicifera was being utilized by turtles for food and was present in 34\% of the 802 turtle samples taken throughout the Hawaiian Islands (Russell and Balazs 1994). By 2005 that quantity had increased to $64 \%$ frequency in the samples, and the quantity of 
TABLE 1

Algae and Sea-Grass Species Listed in Order of Number of Times They Were Found in Turtle Samples, Their Frequency (\% Smp) in 372 Samples, and Average Percentage Amounts or Quantity (Avg \%) in the Samples

\begin{tabular}{|c|c|c|c|}
\hline Species & No. of Times Found & \% Sample & Avg $\%^{a}(\mathrm{SD})$ \\
\hline *Acanthophora spicifera & 237 & $64.0 \%$ & $44.1 \%(32.8)$ \\
\hline *Hypnea musciformis & 154 & $41.4 \%$ & $42.0 \%(32.7)$ \\
\hline *Gracilaria salicornia & 138 & $37.0 \%$ & $40.9 \%(33.0)$ \\
\hline Codium edule & 95 & $25.5 \%$ & $32.1 \%(30.5)$ \\
\hline Laurencia nidifica & 88 & $23.7 \%$ & $12.5 \%(16.5)$ \\
\hline Codium arabicum & 78 & $21.0 \%$ & $28.9 \%(30.5)$ \\
\hline Amansia glomerata & 70 & $18.8 \%$ & $30.0 \%(34.1)$ \\
\hline Dictyosphaeria cavernosa & 62 & $17.0 \%$ & $20.2 \%(27.6)$ \\
\hline Halophila hawaiiana & 59 & $15.9 \%$ & $24.0 \%(14.3)$ \\
\hline Pterocladiella capillacea & 57 & $15.3 \%$ & $35.5 \%(31.3)$ \\
\hline Dictyota acuteloba & 50 & $13.4 \%$ & $8.5 \%(8.5)$ \\
\hline Lyngbya majuscula & 49 & $13.2 \%$ & $4.0 \%(3.5)$ \\
\hline Spyridia filamentosa & 49 & $13.2 \%$ & $15.7 \%(25.7)$ \\
\hline Dictyosphaeria versluysii & 36 & $9.7 \%$ & $5.5 \%(5.8)$ \\
\hline Sargassum echinocarpum & 36 & $9.7 \%$ & $10.9 \%(13.2)$ \\
\hline Halimeda discoidea & 29 & $7.8 \%$ & $7.2 \%(9.6)$ \\
\hline Sargassum sp. & 29 & $7.8 \%$ & $36.3 \%(32.0)$ \\
\hline Gracilaria coronopifolia & 25 & $6.7 \%$ & $20.8 \%(28.9)$ \\
\hline Sargassum polyphyllum & 25 & $6.7 \%$ & $12.6 \%(22.6)$ \\
\hline Valonia aegagropila & 21 & $5.7 \%$ & $3 \%(2.8)$ \\
\hline Halophila decipiens & 15 & $4.0 \%$ & $28.4 \%(28.8)$ \\
\hline Ulva reticulata & 15 & $4.0 \%$ & $33.8 \%(40.0)$ \\
\hline Ceramium sp. & 14 & $3.8 \%$ & Only trace \\
\hline Hypnea cervicornis & 14 & $3.8 \%$ & $23.1 \%(34.2)$ \\
\hline Sphacelaria furcigera & 14 & $3.8 \%$ & Only trace \\
\hline Champia parvula & 13 & $3.5 \%$ & $16.0 \%(19.8)$ \\
\hline Cladophora sp. & 13 & $3.5 \%$ & $51.0 \%(69.3)$ \\
\hline Sphacelaria sp. & 13 & $3.5 \%$ & Only trace \\
\hline Turbinaria ornata & 13 & $3.5 \%$ & $16.5 \%(20.6)$ \\
\hline Codium phasmaticum & 12 & $3.2 \%$ & $18.5 \%(16.9)$ \\
\hline Dictyota sp. & 12 & $3.2 \%$ & Only trace \\
\hline Gelidium sp. & 11 & $3.0 \%$ & $29.3 \%(24.0)$ \\
\hline Microdictyon umbilicatum & 11 & $3.0 \%$ & $6.0 \%$ trace \\
\hline Polysiphonia howeii & 11 & $3.0 \%$ & Only trace \\
\hline Polysiphonia sp. & 11 & $3.0 \%$ & Only trace \\
\hline Laurencia sp. & 10 & $2.7 \%$ & $6.0 \%(6.1)$ \\
\hline Padina japonica & 10 & $2.7 \%$ & $3.0 \%$ trace \\
\hline Cladophoropsis sp. & 9 & $2.4 \%$ & Only trace \\
\hline Dictyota friabilis & 9 & $2.4 \%$ & $18.0 \%$ trace \\
\hline *Eucheuma denticulatum & 8 & $2.2 \%$ & $34.6 \%(31.2)$ \\
\hline Gelidium crinale & 7 & $1.9 \%$ & $1.3 \%(0.8)$ \\
\hline Hypnea pannosa & 7 & $1.9 \%$ & $22.5 \%(21.8)$ \\
\hline Hypnea sp. & 7 & $1.9 \%$ & Only trace \\
\hline Sphacelaria tribuloides & 7 & $1.9 \%$ & $1.6 \%(0.9)$ \\
\hline Gelidium puscillum & 6 & $1.6 \%$ & $35 \%$ (trace) \\
\hline Ulva fasciata & 6 & $1.6 \%$ & $7.8 \%(7.8)$ \\
\hline Zonaria hawaiiensis & 6 & $1.6 \%$ & $2.0 \%$ (trace) \\
\hline Hypnea spinella & 5 & $1.3 \%$ & Only trace \\
\hline *Kappaphycus alvarezii & 5 & $1.3 \%$ & $11.0 \%(7.4)$ \\
\hline Leviellia jungermannioides & 5 & $1.3 \%$ & Only trace \\
\hline Actinotrichia fragilis & 4 & $1.1 \%$ & $5.0 \%(1.4)$ \\
\hline Abnfeltiopsis concinna & 4 & $1.1 \%$ & $60.0 \%(45.6)$ \\
\hline Bryopsis pennata & 4 & $1.1 \%$ & Only trace \\
\hline Cladophoropsis membranacea & 4 & $1.1 \%$ & Only trace \\
\hline Dictyopteris sp. & 4 & $1.1 \%$ & Only trace \\
\hline
\end{tabular}


TABLE 1 (continued)

\begin{tabular}{|c|c|c|c|}
\hline Species & No. of Times Found & \% Sample & $\operatorname{Avg} \%^{a}(\mathrm{SD})$ \\
\hline Hincksia indica & 4 & $1.1 \%$ & Only trace \\
\hline Gracilaria sp. & 4 & $1.1 \%$ & $1.0 \%(1.0)$ \\
\hline *Kappaphycus striatum & 4 & $1.1 \%$ & $23.0 \%(23.6)$ \\
\hline Centroceros clavulatum & 3 & $0.8 \%$ & Only trace \\
\hline Codium sp. & 3 & $0.8 \%$ & $6.7 \%$ trace \\
\hline Dictyopteris plagiogramma & 3 & $0.8 \%$ & $33.3 \%$ trace \\
\hline Dictyota crennulata & 3 & $0.8 \%$ & Only trace \\
\hline Dictyota divaricata & 3 & $0.8 \%$ & Only trace \\
\hline Gelidiella acerosa & 3 & $0.8 \%$ & $39.7 \%$ trace \\
\hline${ }^{*}$ Gracilaria tikvabiae & 3 & $0.8 \%$ & $52.7 \%$ trace \\
\hline Laurencia pennata & 3 & $0.8 \%$ & $14.0 \%$ trace \\
\hline Lobophora variegata & 3 & $0.8 \%$ & $1.0 \%$ trace \\
\hline Microdictyon sechellianum & 3 & $0.8 \%$ & Only trace \\
\hline Microdictyon sp. & 3 & $0.8 \%$ & Only trace \\
\hline Ulva rigida & 3 & $0.8 \%$ & $11.3 \%$ trace \\
\hline Ulva sp. & 3 & $0.8 \%$ & $7.0 \%$ trace \\
\hline Achrochaetium sp. & 2 & $0.5 \%$ & Only trace \\
\hline Bornetella sphaerica & 2 & $0.5 \%$ & $3.0 \%$ trace \\
\hline Bryopsis sp. & 2 & $0.5 \%$ & Only trace \\
\hline Caulerpa sertularioides & 2 & $0.5 \%$ & $10.0 \%$ trace \\
\hline Chondria tenuissima & 2 & $0.5 \%$ & Only trace \\
\hline Chondrococcus bornemanni & 2 & $0.5 \%$ & Only trace \\
\hline Cladophora fascicularis & 2 & $0.5 \%$ & $1.0 \%$ trace \\
\hline Coelothrix irregularis & 2 & $0.5 \%$ & $42.5 \%$ trace \\
\hline Enteromorpha clathrata & 2 & $0.5 \%$ & Only trace \\
\hline Enteromorpha sp. & 2 & $0.5 \%$ & Only trace \\
\hline Galaxaura fasciculata & 2 & $0.5 \%$ & $24.5 \%$ trace \\
\hline Halymenia formosa & 2 & $0.5 \%$ & $5.0 \%$ trace \\
\hline Polysiphonia sparsa & 2 & $0.5 \%$ & $20.0 \%$ trace \\
\hline Rhizoclonium grande & 2 & $0.5 \%$ & Only trace \\
\hline Sargassum obtussifolium & 2 & $0.5 \%$ & $70.0 \%$ trace \\
\hline Scytonema pascheri & 2 & $0.5 \%$ & Only trace \\
\hline Alsidium cymatophilum & 1 & $0.3 \%$ & $10.0 \%$ trace \\
\hline Asparagopsis taxiformis & 1 & $0.3 \%$ & $5.0 \%$ trace \\
\hline Boodlea composita & 1 & $0.3 \%$ & Only trace \\
\hline Caulerpa racemosa & 1 & $0.3 \%$ & Only trace \\
\hline Cladophora seracea & 1 & $0.3 \%$ & Only trace \\
\hline Codium reedae & 1 & $0.3 \%$ & Only trace \\
\hline Colpomenia sinuosa & 1 & $0.3 \%$ & Only trace \\
\hline Dasya sp. & 1 & $0.3 \%$ & Only trace \\
\hline Ectocarpus sp. & 1 & $0.3 \%$ & Only trace \\
\hline Endarachne binghamiae & 1 & $0.3 \%$ & Only trace \\
\hline Galaxaura sp. & 1 & $0.3 \%$ & Only trace \\
\hline Gelidiopsis variabilis & 1 & $0.3 \%$ & Only trace \\
\hline Chondria sp. & 1 & $0.3 \%$ & Only trace \\
\hline Gracilaria bursapastoris & 1 & $0.3 \%$ & Only trace \\
\hline Grateloupia sp. & 1 & $0.3 \%$ & Only trace \\
\hline Griffithsia sp. & 1 & $0.3 \%$ & Only trace \\
\hline Halimeda sp. & 1 & $0.3 \%$ & Only trace \\
\hline Martensia fragilis & 1 & $0.3 \%$ & Only trace \\
\hline Hypnea nidifica & 1 & $0.3 \%$ & Only trace \\
\hline fania capillacea & 1 & $0.3 \%$ & Only trace \\
\hline Laurencia cartilaginea & 1 & $0.3 \%$ & Only trace \\
\hline Laurencia obtusa & 1 & $0.3 \%$ & Only trace \\
\hline Liagora sp. & 1 & $0.3 \%$ & Only trace \\
\hline Padina thivii & 1 & $0.3 \%$ & Only trace \\
\hline Pterocladia bulosa & 1 & $0.3 \%$ & Only trace \\
\hline
\end{tabular}


TABLE 1 (continued)

\begin{tabular}{lccc}
\hline \hline Species & No. of Times Found & $\%$ Sample & Avg ${ }^{a}(\mathrm{SD})$ \\
\hline Rhodymenia anastomosans & 1 & $0.3 \%$ & Only trace \\
Rosenvingea orientalis & 1 & $0.3 \%$ & Only trace \\
Schizothrix calcicola & 1 & $0.3 \%$ & Only trace \\
Siphonocladus tropicus & 1 & $0.3 \%$ & $2.0 \%$ trace \\
Struvea anastomosans & 1 & $0.3 \%$ & Only trace \\
Tolypiocladia calodictyon & 1 & $0.3 \%$ & Only trace \\
Trichogloea subnuda & 1 & $0.3 \%$ & $10.0 \%$ trace \\
*Avrainvellea amadelpha & 1 & $0.3 \%$ & Only trace \\
\hline
\end{tabular}

a "Only trace" indicates that the species never occurred in quantities greater than $1 \%$; "trace" with a percentage indicates that the species occurred in one to three samples in quantities greater than $1 \%$, the average of these few samples is given, and in all other samples it was only a trace.

${ }^{*}$ Nonnative species.

A. spicifera increased from an average of 36.4 to $44.1 \%$ of the amount of algae in the samples (Figure 3). Acanthophora spicifera consistently made up $10 \%$ of the algae in the turtle samples from 1990 to 2005.

Hypnea musciformis was introduced directly into Kāne'ohe Bay from Florida for marine agronomic purposes in January 1974 (Figure 1), and the first turtle crop sample containing H. musciformis was discovered in October 1977 (Russell and Balazs 1994). However, it did not become a food item that was found in turtle samples consistently year after year until after 1985, 11 years after it

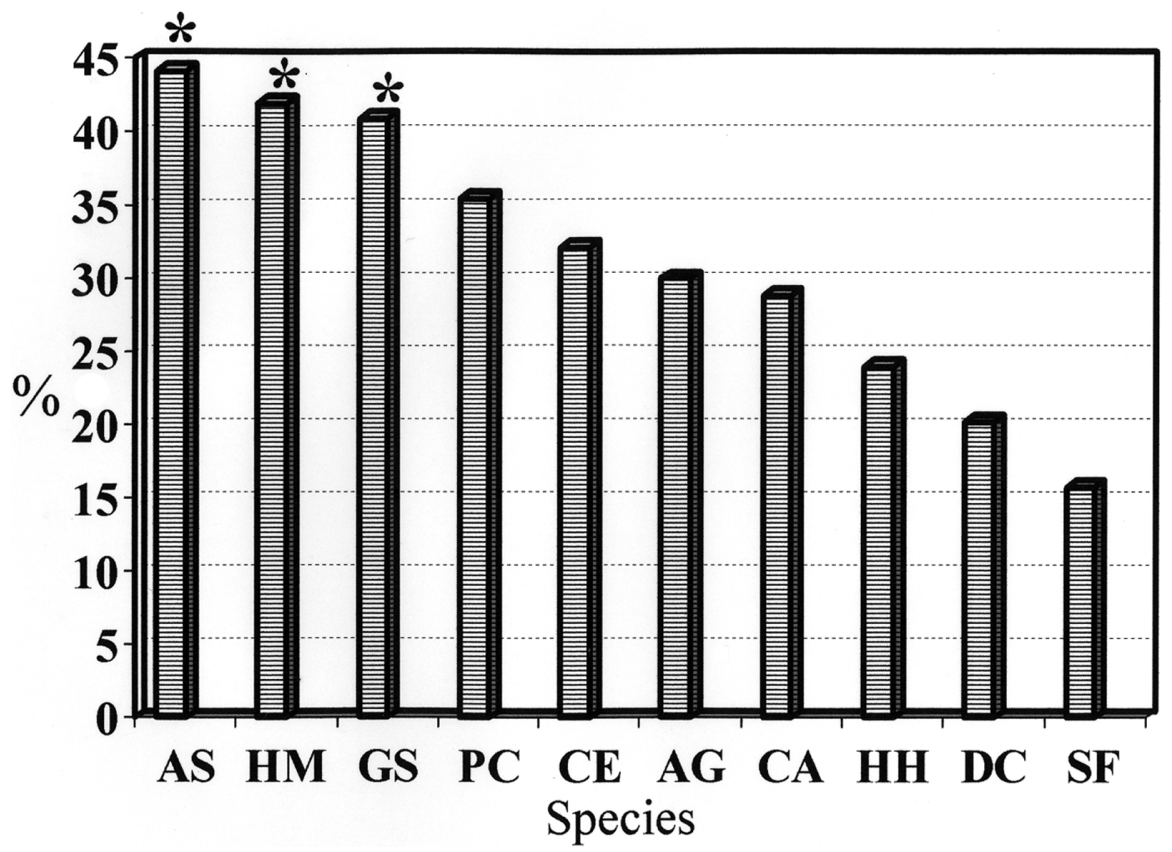

FigURE 2. The 10 algal species most commonly found in turtle samples arranged in order of their frequency. Numbers represent the average percentage amounts they contributed to the samples from a total of 372 samples. Asterisks $\left(^{*}\right)$ indicate nonnative species: AS, A. spicifera; HM, H. musciformis; GS, G. salicornia. The remainder are native species: PC, P. capillacea; CE, C. edule; AG, A. glomerata; CA, C. arabicum; HH, H. bawaiiana; DC, D. cavernosa; SF, S. filamentosa. 


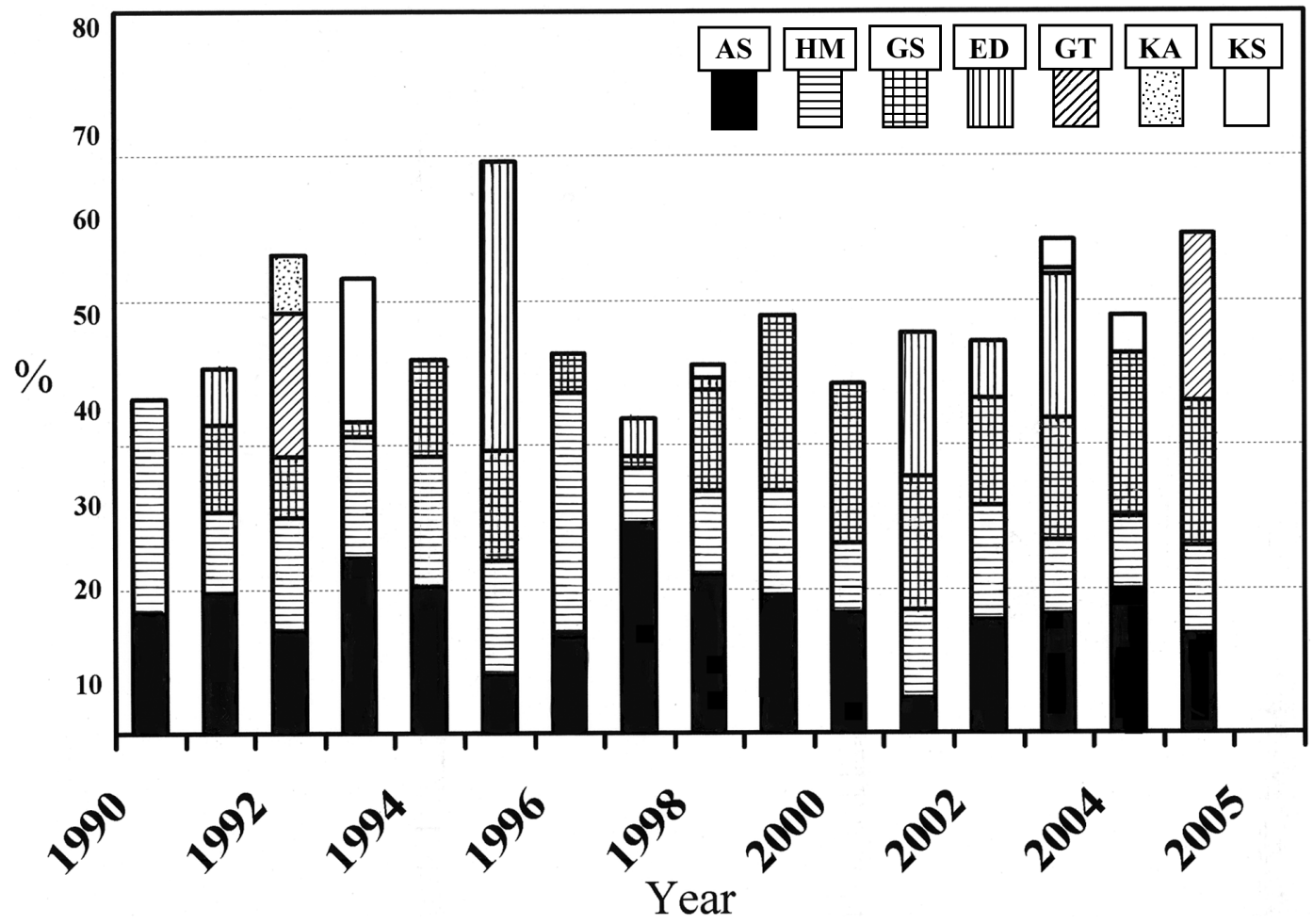

Figure 3. First occurrence and subsequent appearances for nonnative algal species in turtle samples. Bars represent the combined proportional contributions to the total average percentage by only the nonnative species in the samples from 1990 to 2005. AS, A. spicifera; HM, H. musciformis; GS, G. salicornia; ED, E. denticulatum; GT, G. tikvahiae; KA, K. alvarezii; KS, K. striatum.

was introduced to the bay (Figure 3, Table 2). Hypnea musciformis was introduced onto reef flats and has been consistently present in samples and has made up about $5 \%$ of the algae in samples from 1990 to 2005 (Figures 1, 3).
Gracilaria salicornia was introduced to Waikīkī, O'ahu, in April 1971 from Hilo, Hawai' $i$, and later to Kāne'ohe Bay, near Lilipuna pier (Figure 1) in September 1978 (Russell 1981). The first turtle sample con-

TABLE 2

Comparison of Dates Nonnative Algae Were Introduced to Kāne'ohe Bay with Time They Were First Recorded in Crop Samples Taken from C. mydas

\begin{tabular}{lcccc}
\hline \hline Species & Date Introduced & First Sample & Established in the Diet & Lag time (yr) \\
\hline Acanthophora spicifera & 1956 & 1977 & 1977 & $?$ \\
Hypnea musciformis & Jan. 1974 & Oct. 1977 & Oct. 1985 & 11 \\
Gracilaria salicornia & Sept. 1978 & June 1991 & June 1991 & 13 \\
Gracilaria tikvabiae & 1976 & Apr. 1992 & Apr. 1992* & $16+$ \\
Kappaphycus alvarezii & Sept. 1974 & Sept. 1992 & Sept. 1992* & $18+$ \\
Kappaphycus striatum & Sept. 1974 & Sept. 1993 & Apr. 2003* & $20+$ \\
Eucheuma denticulatum & Oct. 1970 & Apr. 1991 & Apr. 1997 & 27 \\
\hline
\end{tabular}

\footnotetext{
* Species are not yet established and are only sporadic components of the turtle diet.
} 
taining G. salicornia was discovered in June 1991 (Figure 3), 13 years after it was introduced to the bay. These data suggest that it takes about 10-13 years for a successful newly introduced nonnative species to become part of the regular (found consistently year to year) diet of C. mydas. Gracilaria salicornia was found in samples consistently year to year only after 1991 (Figure 3), and after 1999 G. salicornia regularly made up about $10 \%$ of the algae in the Kāne'ohe Bay area samples.

Eucheuma denticulatum was introduced to Kāne'ohe Bay from the Philippine Islands in October 1970 and planted on several reefs (Figure 1). It was cultivated extensively on Coconut Island (HIMB) in experiments designed to gather data for the propagation of this marine alga to supply seaweed farms throughout the Pacific (Russell 1983). The first turtle sample found with $E$. denticulatum was discovered in April 1991, 21 years later (Figure 3), and it has been in a total of only eight samples during the 15 years to the end of 2005. Eucheuma denticulatum is still not abundant in Kāne'ohe Bay and has not spread quickly, when compared with $H$. musciformis and $G$. salicornia, and consequently it has been slow in becoming part of the regular diet of turtles during each year.

Kappaphycus alvarezii was introduced from the Philippine Islands to Kāne'ohe Bay in September 1974 and planted on several reefs (Russell 1983) (Figure 1). It first appeared in turtle samples in September 1992 (Figure 3), 18 years later, and sporadically in only five samples during the 13 years through 2005 . Like E. denticulatum, it too is still not abundant in Kāne'ohe Bay, has not quickly spread, and is only slowly becoming a part of the turtles' regular diet.

Kappaphycus striatum was introduced to Kāne'ohe Bay from Pohnpei and the Philippines in 1974 and planted on several reefs (Russell 1983) (Figure 1). It first appeared in turtle samples 20 years later, in April 1993 (Figure 3). Since then it has been discovered sporadically and was only found in four samples during the 12 years to 2005 . Its appearance in turtle samples was noted in 1993 and then much later again only in 2003 (Figure 3 ). It was only able to grow well and spread when it was intensely cultivated on a reef on Coconut Island (HIMB) (Figure 1), and after the cultivation activity ended it has remained in only small amounts in isolated patches in the bay. These last three commercially valuable species were released into Kāne'ohe Bay, where they are continuing to survive without cultivation, do not reproduce rapidly, are not abundant, and have not spread to adjacent areas. It has taken about 20 years for the slower-growing species that do not spread quickly, but that are still successful nonnative species, to become an occasional part of the turtles' diet, and they are not yet consistently found in samples every year.

Gracilaria tikvabiae was introduced from Florida to Kāne'ohe Bay in 1976 and has been cultivated in ponds on marine farms near Mōli'i and Mohi (Figure 1) for the purpose of selling it as a fresh vegetable (Russell 1981). The first time it was discovered in turtle samples was in April 1992 (Figure 3), 16 years later, and it has been found in only three samples during the 13 years since; the last being in August 2005. It has not yet become an established part of the green turtle diet 30 years after it was introduced to Kāne'ohe Bay. This is probably because $G$. tikvabiae is mostly confined to fenced farms, and we have observed that it is located in only a few places near shore adjacent to those seaweed gardens.

Our research shows that green turtles are eventually able to find and utilize newly introduced sources of food as the established algae species become sufficiently abundant in the turtle's foraging locations, although this may take several years.

The diet shift by green turtles toward the abundant nonnative algal species in the Kāne'ohe Bay study area increased from 1977 to 2005 (Figure 4), with the average of nonnative species in turtle crop samples being significantly higher than the native species (Figure 5). The best fit, using natural $\log$ transformation, helps visualize the data and shows that the nonnative algae increased and overtook the declining native algae during approximately 1985-1987 (Figure 4). Also, there are relatively few nonnative species contributing a greater amount to the turtle 


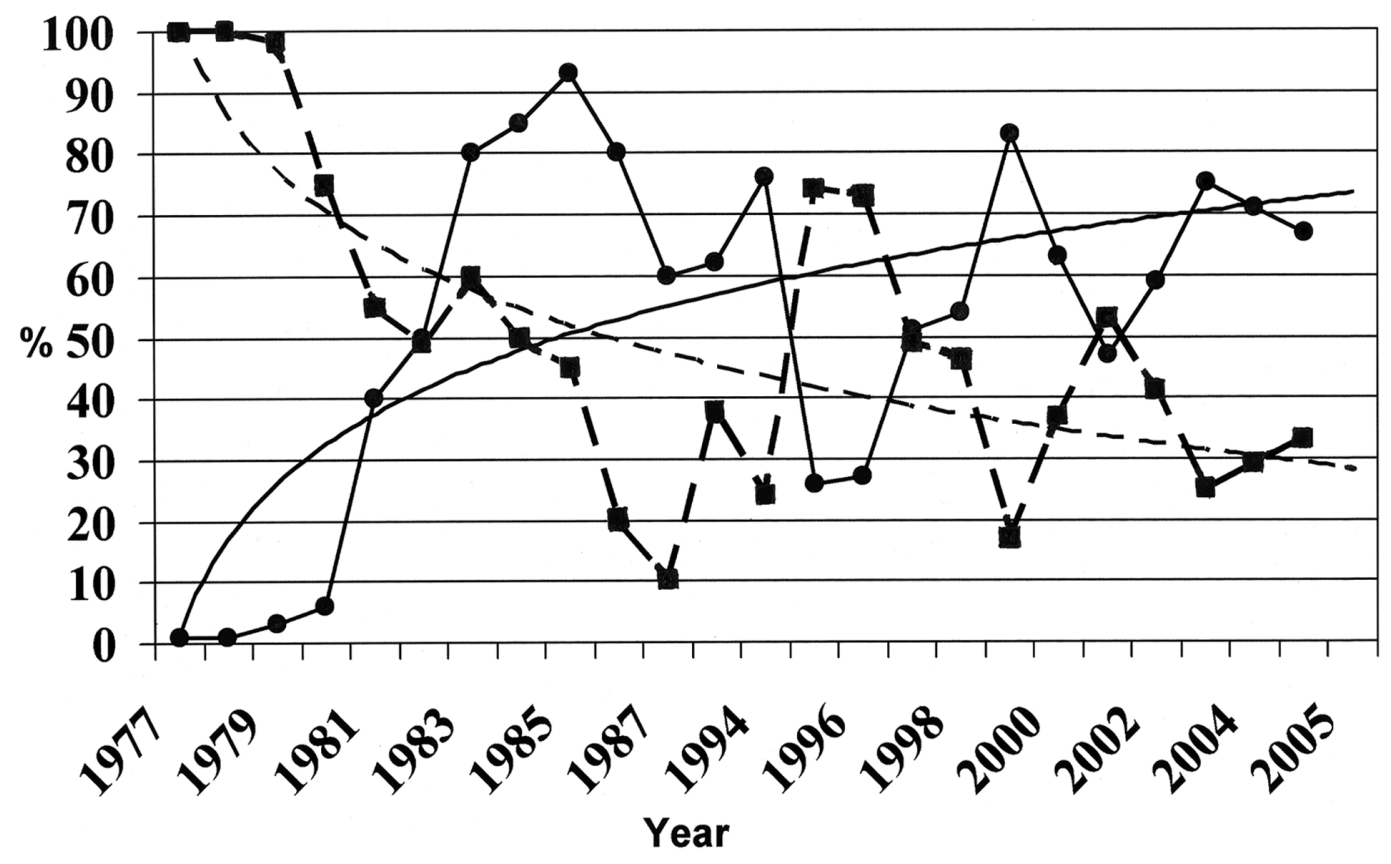

Figure 4. Total average frequencies (\%) of the nonnative algae (circles) in turtle samples compared with the total average frequencies of the native algae (squares) from 1977 to 2005. Solid line represents the best fit for the nonnative data $(y=20.67 \ln (x)+5.95)$, and the dashed line represents the best fit for the native data $(y=-22.99 \ln (x)+102.5)$.

diet from the Kāne'ohe Bay area when compared with the larger number of native species that are each contributing less.

When these data are compared between the small number of nonnative algae and the large number of native algae, the importance of the nonnative species to the diet of the turtles becomes even more apparent (Figure 5). On average, from 1985 to 2005 the five nonnative species composed $58 \%$ of the turtles' food, and the 115 native species composed $42 \%$ of the food turtles were using in the Kāne'ohe Bay area (Table 1). This means each nonnative species was providing about $11.6 \%$ of the food to the turtles, and each native species was only providing $0.4 \%$ of their food. The transition by turtles to use these newly introduced food sources occurred between 1980 and 1990 (Figure 4), after which the turtles chose to eat more of the abundant introduced food sources. It took less than 10 years for Chelonia mydas to actively modify its diet to include nonnative species of algae as they became more abundant in relation to the available native species (Figures 4, 5).

Abundance alone is probably not the only reason the turtles are utilizing the nonnative species, because preference and nutrition are also important. The native species Dictyosphaeria cavernosa and Dictyosphaeria versluysii, succulent green algae, are quite abundant in this region (Russell 1981) but are not utilized as much as expected. They represented only $10-17 \%$ of the samples and only $5 \%$ of the algae present (Table 1). Green turtles in Florida are also selective in what they eat and prefer some algae over others and even avoid eating some algae that are readily abundant and available to them (Gilbert 2005). In the Kāne'ohe Bay region, Halimeda discoi$d e a$, a highly calcified green seaweed, is also abundant and available to the turtles (Russell 1981) but is seldom present in the samples: $7.8 \%$ of the samples and mostly in trace quantities (Table 1). Padina japonica is also abundant on the reef and commonly available 


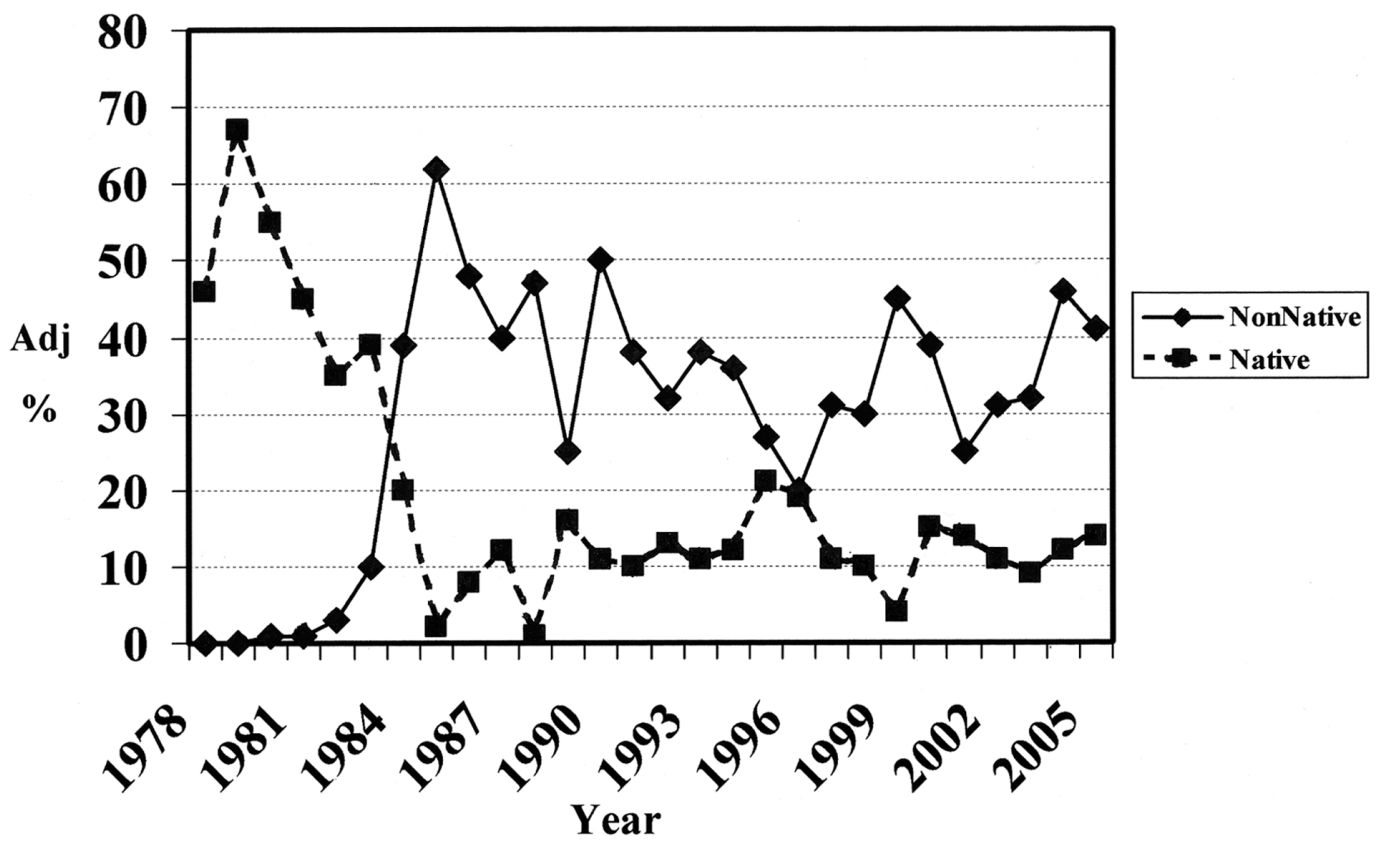

FIGURE 5. Weighted percentages of nonnative algae compared with native algae in the turtle diet. Adjustment was made by dividing the percentage of total algae each year by the number of species that contributed those totals.

to turtles but is utilized only $2.7 \%$ of the time and is probably eaten incidentally along with more important food items, since it too is found mostly in trace amounts. Lyngbya majuscula is a small filamentous cyanophyte that was found in $13 \%$ of the samples, but it was nearly always present in trace amounts (Table 1). It could be an important ingested item related to adverse health effects, even in small amounts, because at times it is known to become toxic and is occasionally present on the reefs in large quantities as a bloom (Arthur et al. 2006).

Gilbert (2005) found that juvenile green turtles in Florida were feeding primarily on Hypnea spp., which is similar to what our data show for Hawai'i. Other species found in the diet of Florida turtles also included Gelidium spp., which are similar to Pterocladellia capillacea in color, texture, and size, as seen in our samples. Gracilaria sp. and A. spicifera were also common in Florida turtle samples and are also common in the Hawai'i turtle samples (Table 1). Hypnea sp., in the Florida study, had a higher nutritional value and was lower in fiber than the less-nutritious species that were not selected by turtles, and the turtles actively avoided those less-valuable species (Gilbert 2005). These results paralleled what was found in Hawai'i but with important differences.

The most common marine plants from turtles found by Arthur and Balazs (2008), in Hawai'i, were A. spicifera, Hypnea sp., P. capillacea, $H$. bawaiiana, $H$. decipiens, and Cladophora sp. All of these species were present in our samples, but $C$. arabicum, $C$. edule, and $A$. glomerata were more important in our samples than the two sea-grass species recorded by Arthur and Balazs (2008). However, their study clearly showed that turtles selectively feed on different species in different pastures; therefore variations in turtle diet between study areas are reasonable and expected.

In addition, the nutritional value of the three most common nonnative algae in turtle samples is similar to that of the native species (McDermid and Stuercke 2003, McDermid 
et al. 2007). These new and abundant nonnative species are now supplying the turtles with an important source of energy and protein in addition to the native species they continue to include in their diet. The diet shift by $C$. mydas to include the introduced algae food sources in the Kāne'ohe Bay region was a behavior pattern that was repeated every time a newly introduced food source became available to them.

\section{CONCLUSIONS}

Important conservation efforts in Hawai' $i$ have successfully reversed the downward trend for $C$. mydas, and as the population appears to be approaching carrying capacity the importance of protecting and maintaining adequate food in their foraging areas becomes critical. The increasing numbers of green turtles in Hawai'i (Balazs and Chaloupka 2004a, 2006, Hays 2004), are directly a result of conservation measures, and appear to be due to turtles finding, selecting, and using newly introduced supplemental seaweed food resources. Green turtle nesters increased noticeably after 1985 and this was during the same time period that turtles began utilizing the new food sources in the study area foraging grounds (Figure 4). These food sources appear to be contributing to the carrying capacity of the green turtle's habitat and also to its recovery in Hawai' $i$.

\section{ACKNOWLEDGMENTS}

For long-term contributions to dietary studies of free-ranging green turtles throughout the Hawaiian Islands we sincerely thank the following individuals, agencies, and organizations: Isabella A. Abbott, Karen Arthur, Bridget McBride, Donna Brown, Sallie Beavers, Ursula and Peter Keuper-Bennett, Dart Bicoy, Shandell Brunson, Emily Carlson, Mike Coelho, John Coney, Walter Dudley, Skippy Hau, Leon Hallacher, Stacy (Kubis) Hargrove, Don Heacock, Cody Hooven, Alan Kam, Regina (Luna) Rudrud, Darren Marshall, Karla McDermid, Ed and Diane Medeiros, Sherwood Maynard, Shawn Murakawa, Bob Morris, Irene Nurzia-Humburg,
Joy Oliveira, Erin Siebert, Russell Sparks, Bill Puleloa, Jason Turner, Bob Rameyer, Marc Rice, Denise Parker, Thierry Work, State of Hawai'i Division of Aquatic Resources and Division of Conservation and Resources Enforcement, Marine Option Program (University of Hawai'i at Mānoa, University of Hawai'i at Hilo, Maui Community College), the Hawai'i Preparatory Academy, and the NOAA Hawaiian Islands Humpback Whale National Marine Sanctuary. For valuable review comments and suggestions on the manuscript we express appreciation to George Antonelis, Alan Bolten, Bruce Mundy, Karla McDermid, Stacy (Kubis) Hargrove, and anonymous journal reviewers.

\section{Literature Cited}

Abbott, I. A. 1999. Marine red algae of the Hawaiian Islands. Bishop Museum Press, Honolulu.

Abbott, I. A., and J. M. Huisman. 2004. Marine green and brown algae of the Hawaiian Islands. Bishop Museum Press, Honolulu.

Arthur, K. E., and G. H. Balazs. 2008. A comparison of immature green turtle (Chelonia mydas) diets among seven sites in the main Hawaiian Islands. Pac. Sci. 62:205-217.

Arthur, K. E., C. J. Limpus, C. M. Roelfsema, J. W. Udy, and G. R. Shaw. 2006. A bloom of Lyngbya majuscula in Shoalwater Bay, Queensland, Australia: An important feeding ground for the green turtle (Chelonia mydas). Harmful Algae 5:251-265.

Balazs, G. H. 1980. Synopsis of biological data on the green turtle in the Hawaiian Islands. NOAA Tech. Memo. NMFSSWFC-7.

Balazs, G. H., and M. Chaloupka. 2004a. Thirty-year recovery trend in the once depleted Hawaiian green sea turtle stock. Biol. Conserv. 117:491-498.

2004b. Spatial and temporal variability in somatic growth of green sea turtles (Chelonia mydas) resident in the Hawaiian archipelago. Mar. Biol. (Berl.) 145:10431059. 
2006. Recovery trend over 32 years at the Hawaiian green turtle rookery of French Frigate Shoals. Atoll Res. Bull. 543:147-158.

Balazs, G. H., R. G. Forsyth, and A. K. H. Kam. 1987. Preliminary assessment of habitat utilization by Hawaiian green turtles in their resident foraging pastures. NOAA Tech. Memo. NMFS-SWFSC-71.

Balazs, G. H., S. K. K. Murakawa, J. Wyneken, and B. A. Schroeder. 1998. Differences in flipper size and esophagus morphology of green turtles from Hawaii and Florida. Pages 137-139 in Proceedings 17th Annual Sea Turtle Symposium, 4-8 March 1997, Orlando, Florida. NOAA Tech. Memo. NMFS-SEFSC-415.

Chaloupka, M., T. M. Work, G. H. Balazs, S. K. K. Murakawa, and R. Morris. 2008. Cause-specific temporal and spatial trends in green sea turtle strandings in the Hawaiian Archipelago (1982-2003). Mar. Biol. (Berl.) 154:887-898.

Doty, M. S. 1961. Acanthophora, a possible invader of the marine flora of Hawaii. Pac. Sci. 15:547-552.

Eldredge, L. G., and C. M. Smith. 2001. A guidebook of introduced marine species in Hawai'i. Bishop Mus. Tech. Rep. 21.

Gilbert, E. I. 2005. Juvenile green turtle (Chelonia mydas) foraging ecology: Feeding selectivity and forage nutrient analysis. M.S. thesis, University of Central Florida, Orlando.

Hays, G. C. 2004. Good news for sea turtles. Trends Ecol. Evol. 19:349-351.

Hirth, H. F. 1997. Synopsis of the biological data of the green turtle Chelonia mydas (Linnaeus 1758). U.S. Fish Wildl. Serv. Biol. Rep. 97 (1): 1-120.

Huisman, J. M., I. A. Abbott, and C. M. Smith. 2007. Hawaiian reef plants. University of Hawai'i Sea Grant College Program Rep. No. UNIHI-SEAGRANT-BA03-02.

McDermid, K. J., and B. Stuercke. 2003. Nutritional composition of edible $\mathrm{Ha}-$ waiian seaweeds. J. Appl. Phycol. 15:513524.

McDermid, K. J., B. Stuercke, and G. H. Balazs. 2007. Nutritional composition of ma- rine plants in the diet of the green sea turtle (Chelonia mydas) in the Hawaiian Islands. Bull. Mar. Sci. 81:55-71.

Phillips, R. C., and C. P. McRoy. 1980. Handbook of seagrass biology: An ecosystem perspective. Garland STPM Press, New York.

Russell, D. J. 1981. The introduction and establishment of Acanthophora spicifera (Vahl) Boerg. and Eucheuma striatum Schmitz in Hawaii. Ph.D. diss., University of Hawai'i, Honolulu.

- 1983. Ecology of the imported red seaweed Eucheuma striatum Schmitz on Coconut Island, O'ahu, Hawai'i. Pac. Sci. $37: 87-106$

1992. The ecological invasion of the Hawaiian reefs by two marine red algae, Acanthophora spicifera (Vahl) Boerg. and Hypnea musciformis (Wulfen) J. Ag., and their association with two native species, Laurencia nidifica J. Ag. and Hypnea cervicornis J. Ag. ICES Mar. Sci. Symp. 194:110-125.

Russell, D. J., and G. H. Balazs. 1994. Utilization of alien alga species by sea turtles in Hawai'i. Pages 93-95 in D. J. Baker and K. Sullivan, eds. Proceedings of the Conference and Workshop on Nonindigenous Estuarine and Marine Organisms (NEMO), Seattle, Washington, 20-23 April 1993. NOAA, Washington, D.C.

. 2000. Identification manual for dietary vegetation of the Hawaiian green turtle Chelonia mydas. NOAA Tech. Memo. NMFS-SWFSC-294.

Russell, D. J., G. H. Balazs, R. C. Phillips, and A. K. H. Kam. 2003. Discovery of the sea grass Halophila decipiens (Hydrocharitaceae) in the diet of the Hawaiian green turtle, Chelonia mydas. Pac. Sci. 57:393-397.

Smith, J. E., C. L. Hunter, and C. M. Smith. 2002. Distribution and reproductive characteristics of nonindigenous and invasive marine algae in the Hawaiian Islands. Pac. Sci. 56:299-315.

Work, T. M. 2000. Sea turtle necropsy manual for biologists in remote refuges. U.S. Geological Survey National Wildlife Health Center Hawai'i Field Station. 